\title{
Research on Life Insurance Marketing Model of Guizhou Province under the Trend of Internet Finance
}

\author{
Xin He \\ School of Finance \\ Guizhou University of Finance and Economics \\ Guiyang, China \\ 121190731@qq.com
}

\author{
Hongmei Zhang* \\ School of Finance \\ Guizhou University of Finance and Economics \\ Guiyang, China \\ zhm1035@qq.com
}

\begin{abstract}
Since the reform and opening-up, The development of insurance industry of our country is very rapid, and keep good situation and development foreground. Guizhou Province as a representative of China's underdeveloped regions, the depth of insurance and the density of insurance has a big gap with the developed provinces. With the rapid development of Internet technology, internet finance brings opportunities and challenges to the traditional financial industry. By studying the marketing mode of life insurance in Guizhou province in the era of internet finance, this paper puts forward the new marketing means to reduce the impact of internet finance on insurance industry, improve the way of life insurance marketing and promote the deep integration of insurance and Internet.
\end{abstract}

Keywords-Internet finance; Guizhou Province; Internet life Insurance marketing; deep integration

\section{INTRODUCTION}

Guizhou Province is located in the southwest of China, and its economic development is relatively backward, the insurance industry developed late. At present, the insurance market of our country is gradually changing from seller's market to buyers. However, the life insurance company's marketing activity is in the certain environment, this kind of environment and is in the continuous change. The marketing process of life insurance Company is a dynamic process that adapts to changing environment and responds to changing environment. Changes in environmental forces or factors can create opportunities for life-insurance marketing as well as some kind of threat. Therefore, life insurance companies must take measures to monitor and forecast the development and change of marketing environment, accurately and carefully understand and grasp the marketing environment, and strive to make the company's business objectives and marketing environment all factors to maintain coordination and balance, in order to ensure the realization of business objectives and the healthy development of the company. The marketing environment of the life Insurance Enterprise is the sum of the factors related to the outside and marketing activities of the life insurance enterprise and the internal influence of the marketing in the life insurance enterprise. The success or failure of the marketing activities of life insurance companies is influenced not only by the external environment, but also by the internal factors. The marketing of life insurance is to combine the external environment with internal factors, coordinate development and achieve dynamic balance. The internal and external environment of life insurance management is complicated; especially the change of external business environment is frequent and unpredictable, such as economic cycle, scientific and technological progress, consumption habit, market demand and other factors, all of which may seriously affect the smooth conduct of life insurance activities and the realization of business objectives. In this regard, life insurance operators should be fully prepared in advance, in view of every major change in the operating environment, to formulate one or more contingency plans and countermeasures to ensure the stability of life insurance business and the realization of business objectives. At the same time, according to the changing situation, at any time to revise and adjust the management strategy to meet the needs of life insurance business activities. At the "same time", according to the changing situation in any time to revise and adjust "the management strategy to meet" the needs of Life insurance business activities. Guizhou life Insurance in the internet finance, in addition to the formulation of the strategy in line with market development law, catering to consumer demand and in line with their own business characteristics, in the actual development of the business has also achieved better results. Through the study of these practices, it can provide reference for the development of Internet finance business of other insurance companies, which has practical guiding significance.

This article can be used for reference to a large number of domestic and foreign research results combined with life's own actual situation to make an analysis, and put forward the corresponding development strategy research results for the insurance industry Internet financial business development to provide a theoretical basis. Life insurance in the Internet financial business strategic planning earlier, through theoretical exploration and practice testing to form a set of concepts and ideas, in the domestic insurance industry in the leading position, the domestic insurance companies are now the internet finance as a core strategy, but the lack of innovative models and experience. Under the background of developing large data industry in Guizhou Province, the Innovation Insurance marketing mode of Internet is more favorable to the further development of insurance industry in Guizhou province.

This work was supported by Guizhou University of Finance and

Economics Insurance Workstation Project. 


\section{LITERATURE REVIEW}

Today, the Internet has become the second most effective way to sell insurance in the United States, which accounts for about 33\% of America's total insurance rate. According to the authorities, the world's insurance business, in the next decade, could have $31 \%$ of commercial risks and $37 \%$ of the risks coming from Internet channels. At present, some enterprises take the lead in using the cloud computing services provided by suppliers to carry out their own business. Perry Luzwick (2001) 's view was that the Internet is becoming a brand new marketing channel, which can connect insurance companies with customers more closely, thus realizing the direct communication between insurance companies and customers, and the old agent sales model will change in the future insurance industry. Mathew Josefowicz (2005) based on the difference between life insurance and property insurance, this paper analyzes the difference between the two insurance fields of the Internet in life insurance and property insurance, concludes that the two kinds of insurance period is longer, which is that the insurance enterprise needs to serve the customer for a long time, So this kind of insurance needs this kind of convenient and efficient service way. Wang Ta (2012) thought that the mobile electronic commerce will keep abreast with the insurance electricity and the net sale, impel our country Insurance Marketing system consummation and the development.

According to the research of the insurance industry at home and abroad, the situation of the insurance industry was analyzed in depth. That is to say, the insurance industry has initially formed a business model dominated by the official website, third-party payment platform, network agent, intermediary agent and Internet insurance Company, mobile platform APP, etc. The emergence of the insurance model of the life insurance Internet indicates that professional Internet team and professional insurance Internet company have entered into the reality.

\section{ANALYSIS ON THE PRESENT SITUATION OF LIFE INSURANCE MARKETING IN GUIZHOU}

\section{A. General situation of life insurance marketing in Guizhou Province:}

Guizhou Province is located in southwest China and the economy is relatively backward. Many insurance companies are relatively traditional marketing methods. Life Insurance Marketing is mainly about the concept of insurance products, development, design and marketing and after-sales service, such as the planning and implementation of the process. That is to say, the insurance company takes the life insurance as the commodity, takes the market as the center, satisfies the insured's demand as the goal, and realizes the insurance company goal the whole series of activities.

\section{B. Characteristics and current situation of life insurance marketing in Guizhou Province:}

At present, due to the advent of the Internet financial era, financial enterprises began to develop rapidly; many insurance companies have also changed their marketing methods. First of all, compared to the previous only a few traditional insurance varieties, more and more Insurance products can meet the different types of industries different needs of the insured. Secondly, due to the economic development and the impact of the Internet financial era, Guizhou province's big data industry rapid rise. Network quickly covered most of the province and network sales have become the main trend of development. Finally, the insurance company's product direction also changed, such as the small amount of financial products also began to become mainstream insurance products.

\section{PROBLEMS AND CAUSES OF LIFE INSURANCE MARKETING MODEL IN GUIZHOU PROVINCE}

\section{A. Existing problems:}

Weak marketing consciousness and backward marketing idea:

Because of the development of economy, marketing system and idea are influenced by past experience. The concept of active marketing is relatively weak, the way of marketing is relatively backward, and whether in the design of products or in the concept of sales has not taken into account the changes in social needs and the hearts of the public.

Market positioning is not clear and product lacks characteristics.

Product design is related to the sale of product. Market research and the prediction of the late market demand is the basis of modern marketing. The positioning of the market is the key to marketing. However, due to many erroneous ideas and the extensive marketing approach, many life insurance companies do not pay attention to market research and market demand forecasts and market positioning. For market segmentation, Target market selection, product development, etc. can not be carried out. It is difficult to adapt to different levels and different areas of consumer demand.

\section{1) Single Marketing Channel}

The traditional way of marketing has been to rely on the company's field direct business, because there is no systematic marketing system. At present, for the life insurance marketing industry in Guizhou Province, the main problem is the reliance on the traditional marketing channel, and the application of the new marketing channel is relatively few.

\section{2) Low quality of marketing team}

Much life insurance industry lacks the professional life insurance marketing talented person. The life insurance company generally lacks the life insurance marketing specialized trainer and the high level marketing supervisor, which causes the marketing team the training insufficiency. Moreover, the education level of Guizhou province is relatively backward compared with many cities in our country. Therefore, there are some problems such as nonstandard business operation, not strong sense of responsibility, and low quality of business.

\section{B. Causes:}

\section{1) The challenge of product innovation}

Along with the advent of the internet era, many life insurance marketing business is slowly breaking the traditional marketing products and traditional after-sales service. Consumers also began to slowly on the internet era of products 
have a new understanding. Compared with the traditional life insurance products, the product variety is richer, the transaction speed is quicker, the premium is cheaper, and the time for the checkup is longer.

\section{2) The challenge of marketing model}

Traditional life insurance Marketing model and marketing system is not sound. The structure of marketing system is unreasonable and the marketing means is backward. The way of marketing is either one-to-one or multiple-way. In Guizhou, people are psychologically defensive about many insurance products and financial products. The challenge of marketing model is one of the main reasons for the current situation.

\section{3) The challenge of marketing channel}

Traditional life insurance marketing channels are generally divided into two kinds, direct marketing and indirect marketing. Direct marketing is usually the life insurance company set up its own marketing team, directly to the needs of consumers to sell. Indirect marketing is the life insurance companies through the membership system to recruit members of the model of the agent. However, with the impact of the internet era, traditional marketing channels no longer adapt to the current rapid development of the economy; therefore, the search for new marketing channels is now the most important of life insurance marketing.

\section{THE CHANGE OF LIFE INSURANCE MARKETING MODE IN GUIZHOU PROVINCE UNDER INTERNET}

\section{A. Changes of marketing objects under Internet:}

Under the traditional life insurance marketing mode, because the marketing way and the marketing channel limitation, the customer group facing is relatively unitary, and the scope is small. But because of the Internet intervention, the collection of information and access to the relatively simple, marketing channels more extensive, customer groups continue to expand the scope.

Because of the economic factors and undeveloped network, many insurance industries are not very aware of competitor information, and the impact is not very big. But in the era of the Internet, the same industry will be concerned about the trend of competitors, in order to quickly seize the market opportunities.

\section{B. Analysis of marketing situation under Internet:}

For the traditional life insurance marketing products, many life insurance products are only the nature of insurance, and not as the nature of financial income. As a result, many people are willing to deposit their money in the bank to earn the appropriate interest rather than to buy insurance. However, with the advent of the Internet financial era, more and more new financial products began to enter the market, which is a new beginning of the life insurance marketing industry.

In Guizhou Province, traditional life insurance marketing methods are generally face-to-face sales and telemarketing. The internet has opened the door to life insurance sales channels, and more and more marketing channels are being used. In addition to traditional marketing channels, many life insurance companies now use the network to develop a number of new and more secure, more convenient and faster sales channels. For example, QQ marketing, micro-letter marketing, the establishment of online sales and other new marketing channels.

\section{THE FUTURE DEVELOPMENT TREND OF LIFE INSURANCE} MARKETING

\section{A. Insurance is more secure and private order is a trend}

With the development of the times, consumer demand is more diversified. Today's insurance market, whether practitioners or consumers, are more rational and mature than ever before. If the life insurance company wants to survive in this market, it can not meet the demand of the consumers simply by the traditional way of production and marketing. Whether in Guizhou or in other regions of China, the future development trend of life insurance marketing industry will be based on different people's different needs of different environments or even different ideas to develop different types of insurance.

\section{$B$. The insurance is flexible and fast and the network sells basically popularize:}

The internet is unstoppable and has become the general direction of the future development of the world. The traditional marketing mode of life insurance is under the impact of Network Marketing mode. Micro-letter, Alipay, QQ, Internet Sales mode has accounted for half of the sales industry. With the advent of the internet era, net life insurance will inevitably become the life insurance industry sales of a major channel. Consumers with demand can have a clear understanding of insurance liability and contract content directly online. Electronic policy can be printed or saved. Funds can be paid directly through the network Third-party platform, convenient, safe, fast. Internet has spread to every industry and even every family, the Internet life insurance sales will also be universal.

\section{Products in various forms, agents to seize the market :}

With the advent of the network and information more and more open, life insurance is more and more people accept. The life insurance industry will become more and more standard, and the traditional agent's team will be slowly replaced. Insurance actuary, insurance planner industry will emerge in large numbers. The traditional door-to-door agent mechanism will change with the approval of the public to the insurance Agent network management. The traditional agent will gradually become a formal agency; agents will appear on various occasions. Agent network in the supervision of the management and constraints, will be very strict in accordance with the rules and regulations to operate, as long as there is a violation of the phenomenon, when immediate rectification or suppression.

\section{COUNTERMEASURES AND RECOMMENDATIONS}

\section{A. Change the marketing idea and pay attention to the marketing work.}

First, Unifying the inside company to the insurance marketing understanding, and attaches great importance to the insurance marketing to realizes the company development strategy important role. At the same time integrating the 
insurance marketing work in the company daily management the track overall consideration. Secondly, the insurance companies should change the marketing concept to meet the market demand as the fundamental purpose of marketing, and ultimately to achieve a win for consumers and insurance companies.

\section{B. Adapt to the diverse needs of today's society to maintain a strong product competitiveness.}

The life insurance company should increase the market research strength and subdivides the market demand. According to the target market needs to develop their own characteristics of the product. Only in this way, life insurance companies in accordance with the different needs of various markets, respectively, to develop different products to meet the different levels of customer demand, so as to establish their own brand.

\section{Rich marketing channels.}

Life insurance companies should improve and update the traditional sales channels, and actively adopt some suitable emerging sales methods. For example: Public welfare activities marketing, network marketing, television marketing, communications equipment marketing and so on. These new marketing methods for the traditional marketing methods, the cost are lower, the transaction more convenient, faster and more agile advantages.

\section{Establish a high-quality marketing team.}

Establishing a top marketing team is a key factor in determining whether life insurance marketing and other insurance companies will win in the market share competition. First of all, Life insurance companies should choose some people who are hard-working, honest and willing to work, and have higher culture quality to join the marketing team. Secondly, should be in the marketing process to strengthen the training of marketing personnel, training content is not only professional skills training, mentality, professional ethics are essential. Finally, the marketing should establish rewards and punishments mechanism, this can improve the enthusiasm of the marketing staff; maintain the stability of the marketing team.

\section{CONCLUSION}

The marketing process of life insurance Company is a dynamic process which adapts to the changing environment and responds to the changing environment. A variety of environmental forces or factors can not only bring opportunities for life insurance marketing, but also may form some kind of threat. Therefore, life insurance companies must take measures to monitor and forecast the development and change of marketing environment, accurate and meticulous understanding and grasp of the marketing environment, and strive to make the company's operating objectives and marketing environment factors to maintain coordination and balance, in order to ensure the realization of business objectives and the healthy development of the company. Because the success or failure of the life insurance enterprise's marketing activities, not only affected by the external environment, but also by the internal factors, life insurance marketing is to combine the external environment with the internal factors, coordinate development and achieve a dynamic balance.

\section{ACKNOWLEDGMENT}

This work was supported by Guizhou University of Finance and Economics Insurance Workstation Project--The analysis of life insurance demand in underdeveloped areas.

\section{REFERENCES}

[1] Le Xiuchen. Research on internet marketing strategy of insurance company's life insurance products [D]. Shanghai Jiao Tong University. 2014. "In Chinese"

[2] Xiao Jianyou. Yuan Xin. Research on life Insurance marketing strategy under mobile internet background [J]. Financial Perspectives Journal. 2014(2):2-5. "In Chinese"

[3] Xia Jin. Research on marketing model under internet age[J]. The World Of Labor Security. 2015. "In Chinese"

[4] Chang Dasheng. On the marketing problem and strategy of life insurance[J]. Modern Business, 2011(18). "In Chinese"

[5] Lu Jifei. Research on Internet business marketing mode of HK life insurance Company [D]. Lanzhou Jiao Tong University. 2014. "In Chinese"

[6] Li Tingming. Guizhou insurance industry fully devote to flood claim work[J]. China Insurance, 2011(6):67. "In Chinese"

[7] Ruan Chao. Research on product innovation strategy of XC life Insurance company based on internet [D]. Zhejiang University of Technology. 2015. "In Chinese"

[8] Tang Canghuai. The way to improve the quality of life insurance marketing Service [D]. Tianjin University. 2009. "In Chinese" 